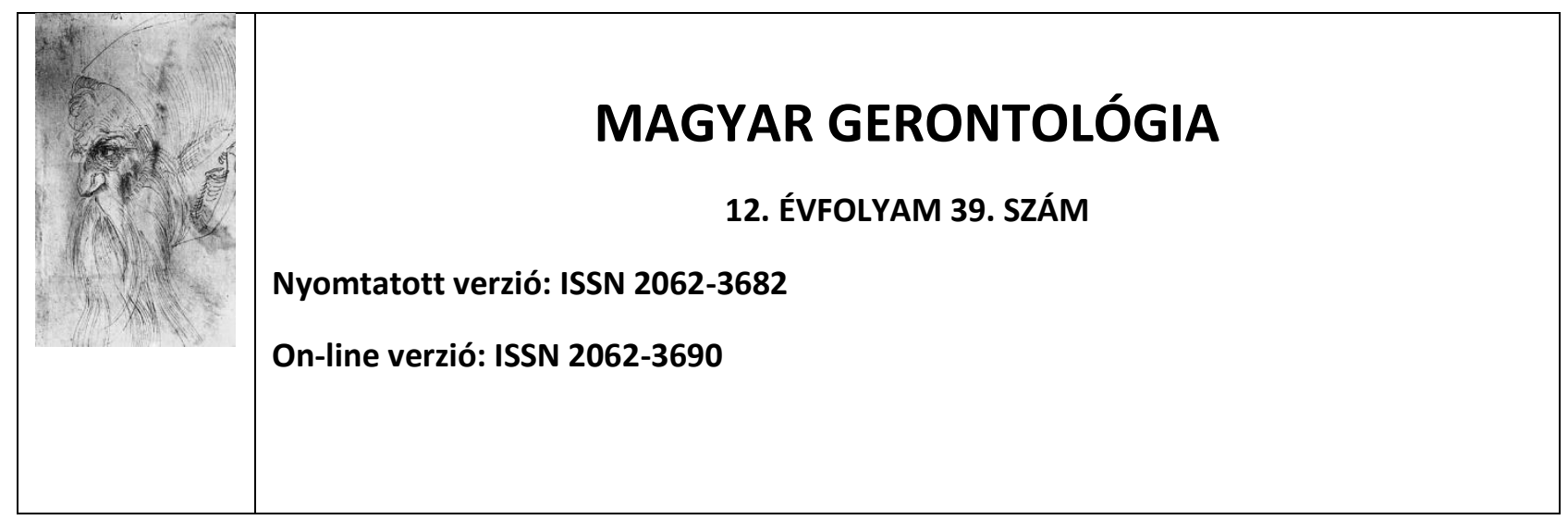

\title{
A DIGITALIZÁCIÓ NÉHÁNY ELEMÉNEK IDŐSEKET ÉRINTŐ HATÁSAI - KARANTÉN ELŐTTI HELYZETKÉP
}

\section{Bene Ágnes ${ }^{1}$, Móré Marianna², Zombory Júlia ${ }^{3}$}

${ }^{1}$ Egyetemi tanársegéd, Debreceni Egyetem Egészségügyi Kar, Gerontológiai Tanszék, PhD hallgató, Debreceni Egyetem Humán Tudományok Doktori Iskola

${ }^{2}$ Dékán, egyetemi docens, Debreceni Egyetem Egészségügyi Kar, Gerontológiai Tanszék

${ }^{3}$ Projektmenedzser, Moholy-Nagy Mủvészeti Egyetem Innovációs Központ

Levelező szerző elérhetősége:

Bene Ágnes

Debreceni Egyetem Egészségügyi Kar, Gerontológiai Tanszék, PhD hallgató, Debreceni Egyetem Humán Tudományok Doktori Iskola

e-mail: bene.agnes@foh.unideb.hu

telefon: +36-30-233-0354

\section{Absztrakt}

Az idősek számának és arányának növekvő tendenciája egyéb változásokkal párhuzamosan jelentkezik, ami nem csak kihívást jelent az ellátórendszereknek, hanem az időskori aktivitás fenntartásával lehetőségek széles spektrumát nyitja meg az idős személyek előtt. Az egyik ilyen lehetőség az idősoktatás, azon belül is a szaporodó Senior Akadémiák, a hazai felsőoktatási intézmények idősoktatási kezdeményezései. Ugyanakkor a XXI. századi változások egyik legmarkánsabb eleme a digitalizáció, ami az idősoktatásban is új szerepet készül betölteni a közösségi terektől való kényszerü távolmaradás okán. A tanulmány a digitalizáció néhány 
területének társadalmi hatásait írja le, kifejezetten az idősebb korosztályok szempontjából. Az egészségügyi aspektusokon túl két terület, a közösség támogató ereje, illetve az elmagányosodás ellen ható törekvések adják az innovatív megoldások társadalmi jelentőségének gerincét hazánkban. A tanulmány a pandémiát megelőző időszak helyzetképét rögzíti az aktív idősödés digitalizációval összefüggő néhány meghatározó területén.

\title{
Kulcsszavak: idősoktatás, digitalizáció, aktív idősödés, idős fogyasztó
}

The impact of some elements of digitisation and education for the elderly before the quarantine situation

\author{
Ágnes Bene, Marianna Móré, Júlia Zombory
}

\begin{abstract}
Digitalisation is one of the most important elements of the changes of the 21 st century. The study describes the social impact of some areas of digitalisation, especially for the older generations. Beyond the health aspects there are two areas - the supporting power of the community and the fight against loneliness - which give the core of the social importance of the innovative solutions in Hungary
\end{abstract}

Keywords: gerontoeducatoin, active aging, elderly consumer

Die Auswirkungen einiger Elemente der Digitalisierung und der Altenbildung vor der Quarantänesituation

Ágnes Bene, Marianna Móré, Júlia Zombory

\begin{abstract}
Abstrakt
Die Digitalisierung ist einer der bedeutendsten Elemente der Veränderungen des 21. Jahrhunderts. Die Studie beschreibt die gesellschaftlichen Auswirkungen einiger Bereiche der Digitalisierung, insbesondere für die älteren Generationen. Über die gesundheitlichen Aspekte hinaus sind zwei Bereiche - die unterstützende Kraft der Gemeinschaft und die Bekämpfung
\end{abstract}


von Einsamkeit -, die den Kern der gesellschaftlichen Bedeutung von den innovativen Lösungen in Ungarn geben.

\section{Bevezetés}

Az előrejelzések szerint Magyarországon 2060-ra a 65 év felettiek száma eléri a népesség 29\%-át, ami egyben azt jelzi, hogy 40 év múlva várhatóan majdnem minden harmadik ember 65 évnél idősebb lesz (Monostori, 2015). Ezen előrejelzések is rámutatnak az idősek létszámának és arányának egyidejű növekedésére. A gazdasági élet szereplőinek szembe kell nézniük a nagyszámú idős munkavállaló megjelenésével (és maradásával), az ebből fakadó helyzettel. Móré (2015) szerint az idősebb generációk olyan képességekkel és kompetenciákkal rendelkezhetnek, amelyek termelékenységi szempontból jól hasznosíthatók. A szakmai és élettapasztalatuk számos helyzetben válhat szervezeti előnnyé. Optimista előrejelzések szerint az idősebbek bizonyos foglalkozási ágakban pótolhatják a szakemberhiányt, az érem másik oldalát tekintve, munkából való kiesésükkel csökkenhet a termelékenység. Akár a munkahelyen maradva (teljes munkaidőben vagy részben), akár a nyugdíjas években új irányokat felfedezve az idősek társadalmi aktivitásának fenntartása hozzájárulhat az elöregedő társadalom problémáinak orvoslásához.

Ahhoz nem fér kétség, hogy az egészségtudatos magatartás összefügg az egészségi állapottal (Libicki \& Fedor 2020). A testi egészség mellett a mentális és érzelmi jóllét fenntartása vagy adott esetben meg- vagy akár visszaszerzése kiemelt jelentőséggel bír az aktív idősödésben. Pinker (2017) szociálpszichológiai kutatásokkal igazoltan hangsúlyozza a személyes találkozások, kontaktusok (szem, mimika, érintés, stb.) a közösségbe ágyazottság (szociális integráltság), valamint a közeli családi és baráti kapcsolatok jelentőségét a pozitív életkilátásokban, a minél hosszabb, aktív életben. Patyán (2018) az életminőség javításának lehetőségeit hangsúlyozza az idősek társadalmi aktivitásának elősegítésével.

A XX. század végén és a XXI. században világszerte - így Európában is - a digitalizáció olyan változásokat hozott, amelyek a gazdaságot és a társadalmat egyaránt érintik. Ebből az idősebb generációk sem maradnak ki. Az őket leginkább érintő változások nagy része az egészségügyben és a kommunikációban történik (Ujváriné Siket et al. 2020; Pihlainen, Kärnä \& Koupio, 2019; Ehlers \& Hess, 2019). A diagnosztikában a korai felismerés nyújtotta előnyök (Williams, Weakley, Cook \& Schmitter-Edgecombe, 2013) sürgették az okos eszközök elterjedését, de a mikrosebészet vagy a művégtagok fejlesztése, a 3D nyomtatás (Gallisti \& 
Rohner, 2019) mára már szerves részét képezik az egészségügyi ellátásnak. Az egészségügy digitalizálódása innovatív folyamat, ugyanakkor az eredmények jelentősen hozzájárulnak az idős emberek egészségügyi állapotának és életkörülményének javításához.

Jelen tanulmány első részében az időskorú személyek néhány olyan jellemzőit mutatjuk be, amelyek befolyásolják a későbbiekben tárgyalt innovációk idősekre gyakorolt hatásait.

Ezt követően a digitalizációval összefüggő olyan területek időseket érintő társadalmi hatásait mutatjuk be, amelyek célja az idős személyek közösségbe ágyazása vagy egy másik szemszögböl tekintve az elmagányosodásuk csökkentése.

\section{Időskorúak}

A Bajusz - Jászberényi szerzőpáros (2013) hangsúlyozza, hogy az időskor meghatározása fókuszfüggő. Leírják, hogy az Európai Bizottság 2005-ben kiadott, az idősödő Európával kapcsolatos iránymutatásokat (policy) összefoglaló munkája, a Zöld könyv alapján a „harmadik kor” generációi: (1) az idősödő munkavállalók (55-64 évesek), az idősek (65-79 évesek) és az aggok (80 felettiek). Egy másik, a különböző generációk internet és médiafogyasztását vizsgáló hazai kutatásban az ,idősebbek” csoportját a 40 év fölöttiek alkották (Hack-Handa \& Pintér,2015). A hazai felsőfokú intézményekhez kapcsolódó idősoktatási kezdeményezések nagy része célcsoportként az 50+-os korosztályt határozza meg (Bene, 2017). Egyetértve Bajusz és Jászberényi (2013) kijelentésével, az időskort jelen tanulmánnyal összefüggésben úgy határozzuk meg, hogy idősnek azon személyek számítanak, akik annak érzik magukat. Természetesen ez a meghatározás az időskorúak alsó korhatárát érintheti és összecseng a szakirodalomban „feel age"-ként definiált fogalommal (Logan, Ward \& Spitze, 1992; Montepare \& Lachman 1989). Azt is hangsúlyozni kell, hogy az idősek csoportja nem tekinthető homogénnek, eltérő öregedési útvonalak, folyamatok léteznek, függően a gazdasági és szociokulturális jellemzőktől, a nemek és családi státuszok, egyéb környezeti tényezők meghatározottságától (Kleisz, 2016).

Az időseket érintő fiziológiai változások sokrétűek. A fiziológiai változások jelentősebb érzékszervi és néhány mentális aspektusán túl viselkedésbeli változások is jellemzik az időseket, aminek háttere összetett: a megváltott fizikai és mentális kondíció, a folyamatosan változó környezeti kihívások, és nem utolsó sorban a megváltozó élethelyzet (pl. nyugdíjazás, nagyszülővé válás). Semsei (2015) a gazdasági aktivitás megszünésével markánsan megváltozó életstílust hangsúlyozza. 
A további pszicho-szociális és életstílust befolyásoló jellemzők még inkább árnyalják a helyzetképet (Bene, Balázs \& Kun, 2019 nyomán):

- Rendszeres jövedelemmel rendelkeznek (nyugdíj).

- Sok szabadidővel rendelkeznek.

- Sokan élnek egyedül.

- Sokuk családja, gyermeke, unokája, dédunokája távol él.

- Az elszigetelődés, elmagányosodás veszélyezteti őket.

- Tagjai lehetnek nyugdíjaskluboknak, más aktív nyugdíjas közösségeknek. Eljárhatnak rendezvényekre, hivatalokba, pénzintézetekbe.

- A mindennapi tevékenységeik során van idejük és lehetőségük a személyes párbeszédek folytatására helyi közösségekben.

- Részt vehetnek az egyre bővülő idősoktatásban.

- Bekapcsolódhatnak közösségekbe, kapcsolódhatnak kezdeményezésekhez (pl. sport, önkéntes munka) az online térben.

- Egészen másként motiválhatók, mint az aktív korúak. Időnként indokolatlanul nagy kockázatot vállalnak, akár tudatosan vagy megfontolás nélkül.

- A maitól lényegesen különböző közegben szocializálódtak, az információfeldolgozási, probléma-megoldási sémáik általában nem naprakészek, nem segítik kellően az érdekérvényesítésüket.

- A technológiai és akár nyelvi változások az ellen hatnak, hogy tudatos legyen fogyasztói viselkedésük (szolgáltatások fogyasztása pl. idősoktatás).

\section{Internet és idősek}

Az internethasználat tekintetében az idősebb korosztályok nagy lemaradásokkal küzdöttek egészen az utóbbi évekig. Magyarországon a 65-74 éves korosztály 30\%-a volt internethasználó 2014-ben. Ahogy ez az 1. ábrán látható, a hazai adat az európai országok alsó középmezőnyében helyezkedik el. 
Figure 3.8. Internet users by age, 16-24 and 65-74 year-olds, 2014

As a percentage of population in each age group

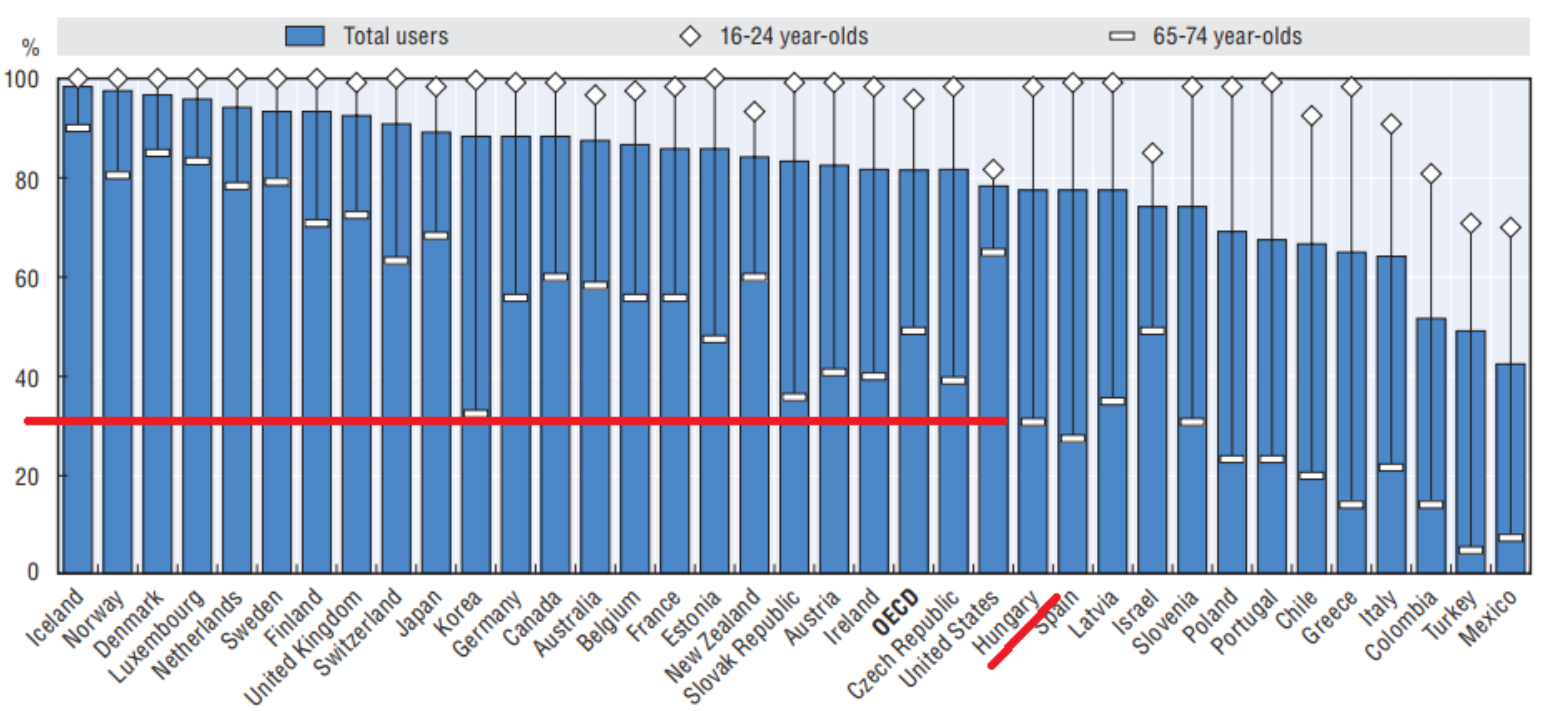

1. ábra Internethasználat az OECD országokban 2014-ben korcsoportok szerint (OECD 2015:138)

2016-ban már a 65-74 éves korosztály több, mint 50\%-a internethasználó volt Magyarországon (OECD, 2017). A 2. ábrán az is látható, hogy ezzel a több, mint 20\%-os növekedéssel (és csupán 2 év alatt) még mindig nem sikerült elérni az OECD átlagot, ugyanakkor ha csak a világtrendeket tekintjük, további növekedés várható a hazai idősebb internethasználók körében.

Figure 4.9. Internet users by age, 2016

As a percentage of the population in each age group

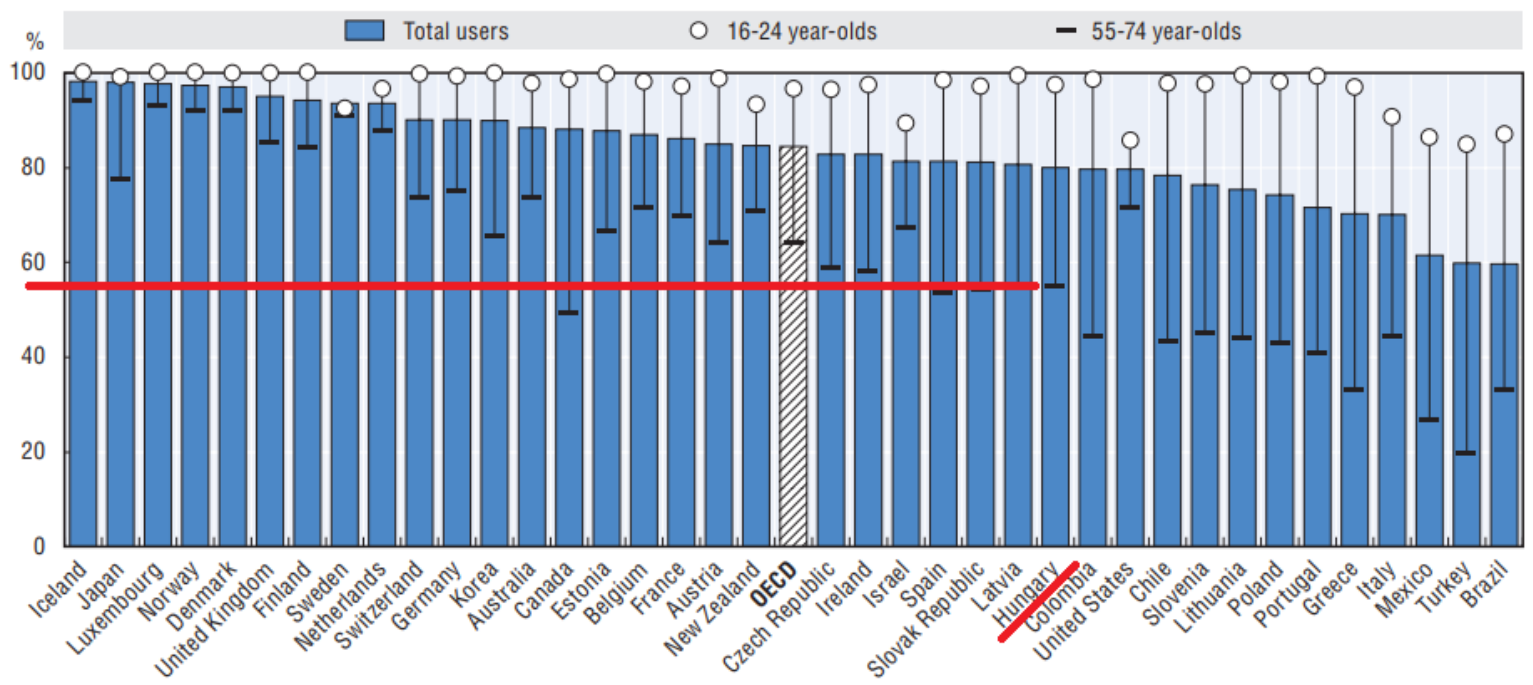

2. ábra Internethasználat az OECD országokban 2016-ban korcsoportok szerint (OECD 2017:169) 
A 2018-as adatokat összefoglaló KSH (2019) jelentésben az internethasználók számának további növekedését írják le. Ennek hátterében elsősorban a hazai internet-ellátottság növekvő színvonalát, és az okostelefonok használatának további elterjedését látják a lakosság egyre szélesebb körében. A valamikor már internetet használók aránya 2018-ban elérte a lakosság $84 \%$-át.

A gyakori internethasználók korcsoportonkénti megoszlását mutatja a 3. ábra. Még mindig jelentős szakadék mutatkozik a fiatalabb generációk és az idősebbek, különösen a 65-74 éves korosztály gyakori internethasználatában.

A gyakori internethasználók aránya korcsoportonként, 2018

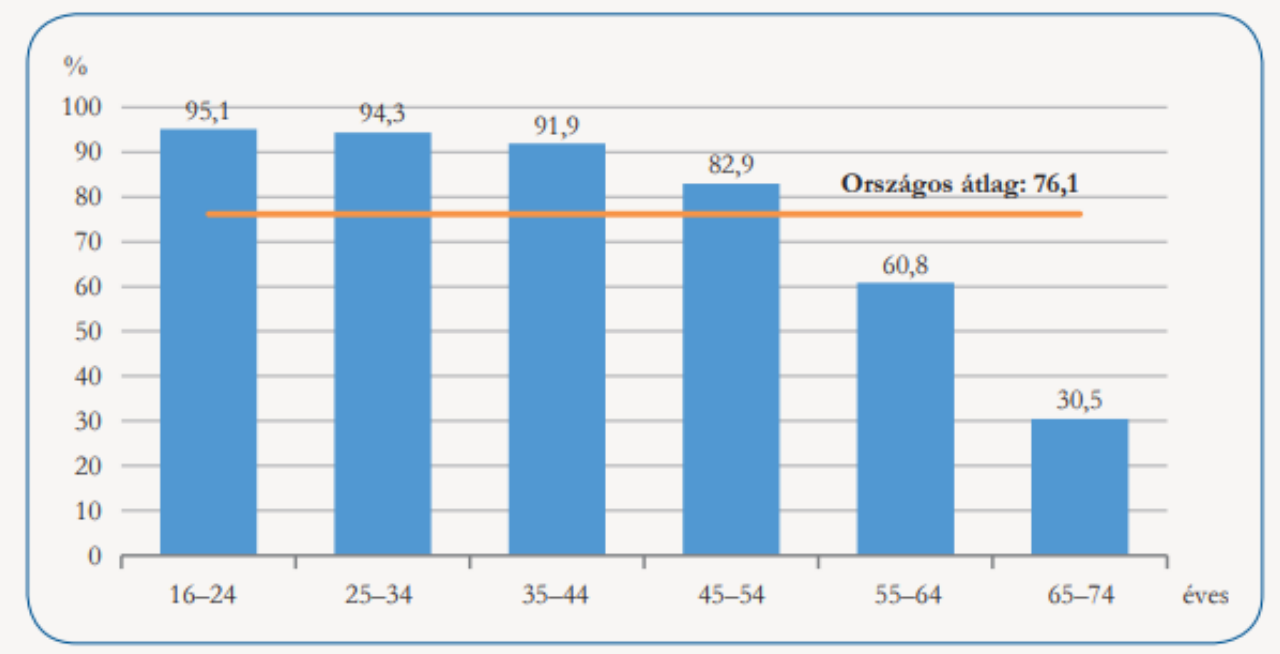

3. ábra Gyakori internethasználók aránya Magyarországon 2018-ban korcsoportok szerint (KSH, 2019:31)

Az internet használati szokásokban generációs különbségek azonosíthatók. A 2017-es generációs internethasználati szokásokat áttekintve (4. ábra) látható, hogy a vizsgált területek közül ez a korosztály leginkább böngészésre $(45,2 \%)$ használja az internetet, és legkevésbé online TV adások nézésére $(8,1 \%)$. 


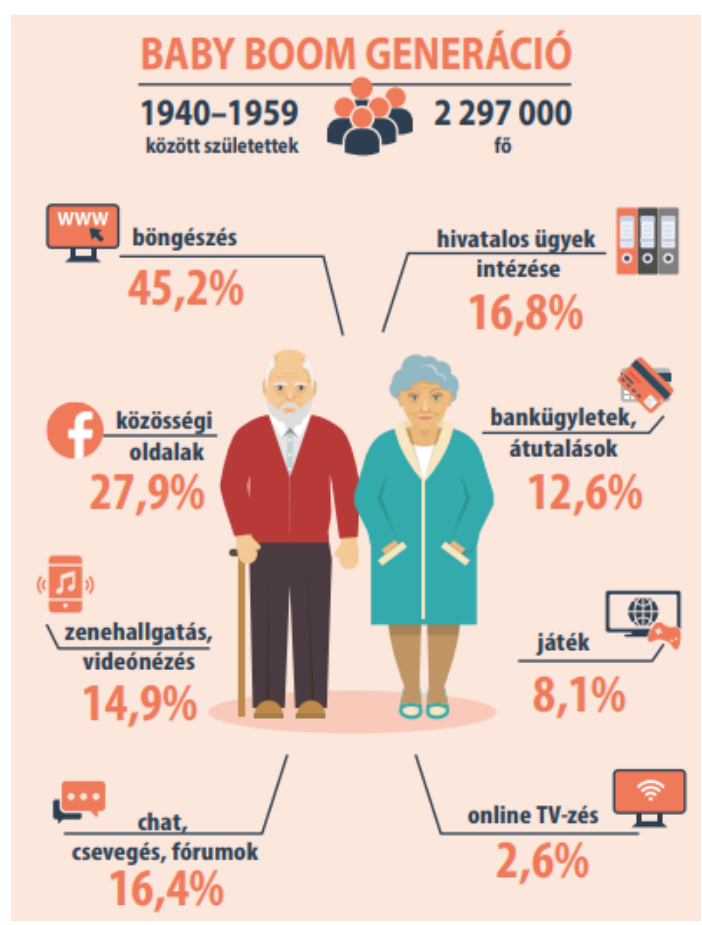

4. ábra A Baby boom generáció internethasználati szokásai 2017-ben (KSH, 2018)

A közösségi oldalak használata évről évre emelkedő tendenciát mutat ebben a korosztályban (KSH, 2019). 2017-ben a közösségi oldalak használata mellett (27,9\%) a zenehallgatás és videó nézés $(14,9 \%)$, illetve a csevegés, fórumozás is számottevő volt a korosztály internetezési szokásaiban.

Kifejezetten az idősebb korosztályoknak szóló informatikai oktatások szervezésre már jóval a 2010-es évek előtt is növekvő igény mutatkozott (például Sz. Molnár, 2005). Országszerte indítanak időseknek szóló IKT tanfolyamokat az utóbbi években egyre nagyobb számban. Ezek szervezői gyakran önkormányzati intézmények, oktatási intézmények, non profit szervezetek, például idős szervezetek is (például Molnár, 2020; Mile, 2019; Hegyesiné Orsós, 2019).

A 2018-as IKT oktatásban résztvevők helyzetképét mutatja be az 5. ábra. Az 55-74 éves korosztály 10\%-a vett részt a különböző IKT képzési tevékenységek közül legalább egy képzési tevékenységben. A különböző oktatási formákban a korosztály részvétele az alábbiak szerint alakult:

Ingyenes online képzés vagy önképzés $(5,3 \%)$

A munkavégzés közbeni képzés, a munkavégzéssel kapcsolatos készségek fejlesztésére $(4,8 \%)$ Közprogramok vagy közintézmények által nyújtott ingyenes képzés (nem a munkaadó által szervezett képzések) (1,6\%)

A munkaadó által szervezett és fizetett képzés $(3,8 \%)$

Fizetős tanfolyam önfinanszírozással $(0,9 \%)$ 
Az egyes IKT-képzéseken résztvevők aránya korcsoportok szerint, 2018*

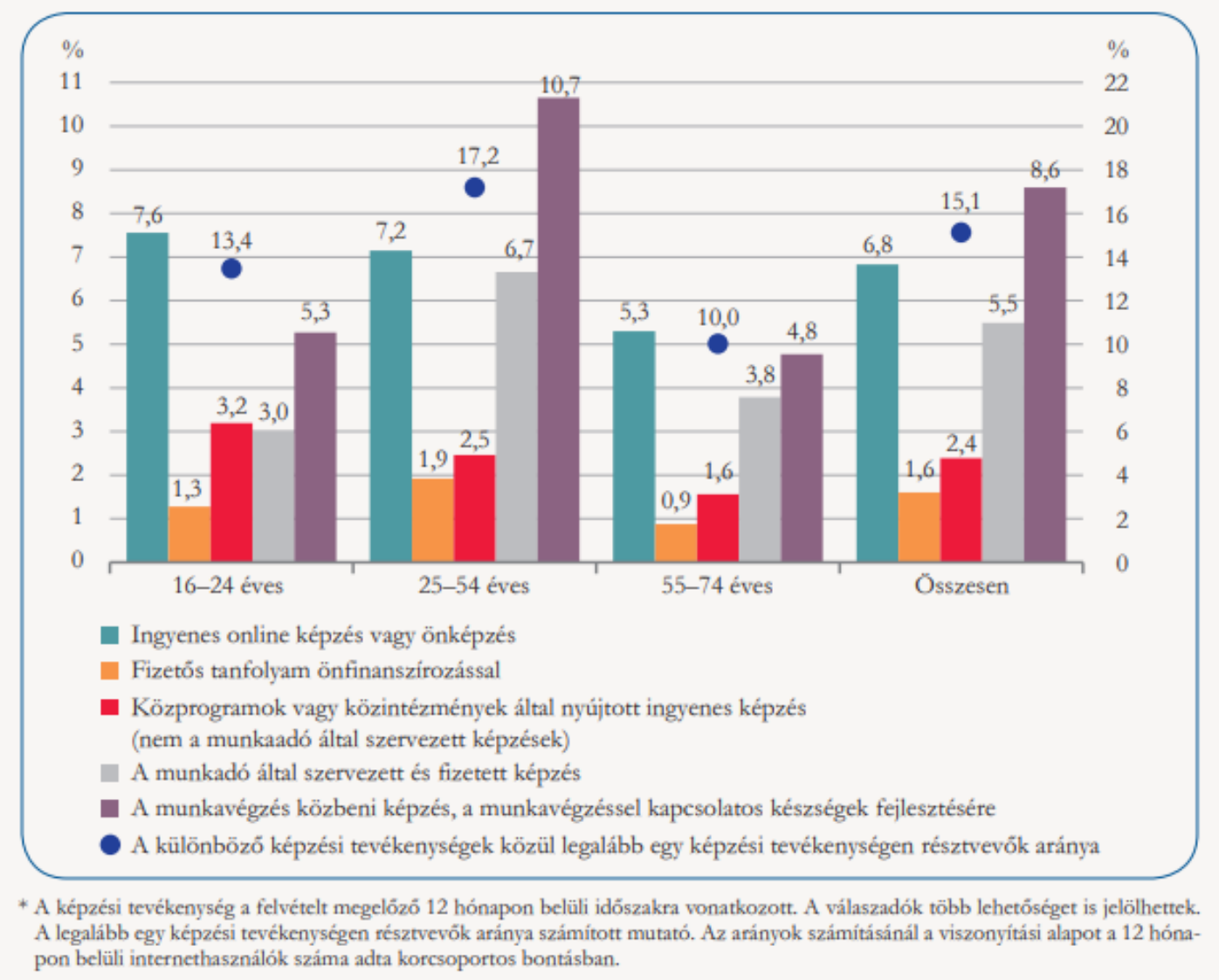

5. ábra IKT képzésben résztvevők korcsoportok szerint, a különbözö képzési formákban 2018-ban (KSH, 2019:41)

Az ingyenes online képzések és önképzések ebben a korosztályban nem sokkal maradnak el az átlagtól, sőt az önfinanszírozásban megvalósuló képzések sem tủnnek el, ami azt jelezheti, hogy olyan motivált idősek is fordulnak az informatika és infokommunikáció tanulmányozása felé, akiket nem elsősorban a munkavégzésükhöz szükséges készségek elsajátítása motivál, hanem egyéb motiváló tényezők, mint például az ismeretszerzés, új készségek elsajátítása, fiatalabb családtagjaikkal, a távoli rokonokkal, ismerősökkel való kapcsolattartás.

A Magyar Kormány a 2010-es évek közepén kezdett el stratégiai szinten, transzparensen a digitalizációval foglalkozni. Célként az ország polgárainak felkészítését tüzték ki az egész világra, a mindennapi életre, a vállalkozások és a közigazgatás szervezésére és müködésére egyaránt kiterjedő digitális átalakulásban. A Digitális Jólét Programot (DJP) 2015-ben indították, „melynek legfontosabb feladata annak támogatása, hogy Magyarország minden polgára és vállalkozása, miként a magyar nemzetgazdaság is a digitalizáció nyertese lehessen" (DJP 2.0, 2017:3). 
Ennek a további növekedési potenciálnak egyik erős pillére a Digitális Jólét program 2.0, 2017. július 19-én jelent meg a Magyar Közlönyben a Kormány 1456/2017. (VII. 19.) határozata a DJP 2.0 elfogadásáról. A DJP 2.0 41. bekezdése tartalmazza a digitális jólét jegyében is kívánatos egészség-nyereség fókuszú intézkedéseket. Ezek:

- Magyarország Digitális Egészségipar-fejlesztési Stratégiájának (DEFS) kidolgozása;

- Idősügyi Infokommunikációs Modellprogram kiterjesztése (DJP 2.0:12).

\section{Célként}

- az idős személyek saját otthonukban tartását;

- a formális szociális gondozás és az egészségügyi ellátórendszer tehermentesítését;

- a gondozó családtagok idősgondozásból eredő terheinek és munkavállalásának összeegyeztethetővé tételét;

- és a generációk közötti kommunikáció erősítését fogalmazták meg (DJP2.0:82).

A kormányzati erőfeszítések egyik eredménye, hogy egyre szélesebb körben lehet a közigazgatási ügyeket elektronikus úton intézni (KSH 2019).

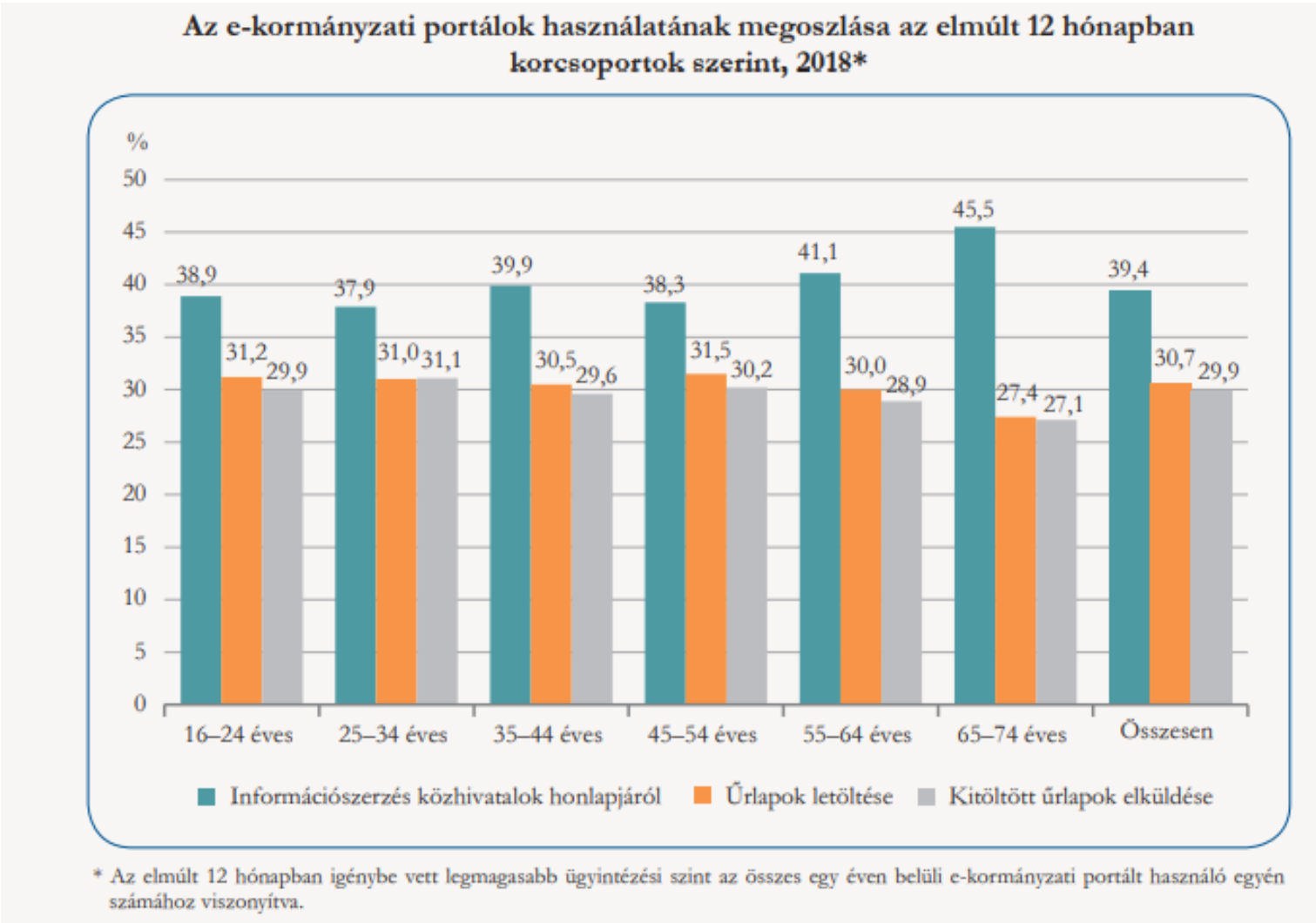

6. ábra E-kormányzati portálok használata korcsoportok szerint Magyarországon 2018-ban (KSH, 2019:37) 
A 2018-as adatokat áttekintve (6. ábra) az e-kormányzati portálok használatában a 65-74 éves korosztály élen járt a közhivatalok honlapjairól történő információ szerzésben. Öket az 55-64 éves korosztály követi ebben a toplistában. Ezen adatok is alátámasztják, hogy ha az idős személyeknek lehetôségük van (készség, technikai háttér, internet hozzáférés) rá, akkor szívesen használják a világhálót információszerzésre. Ez különösen annak fényében figyelemre méltó, hogy, - ahogy azt a korábbiakban leírtuk, gyakran nem csak a saját ügyeikben járnak el, hanem a családtagok ügyeiben is, kihasználva a megnövekedett szabadidejük adta lehetöségeket.

\section{Hatások}

Az elérhetö, biztonságos és megfizethető internet elönyei lehetnek: a befogadás, a hatékonyság és az innováció, egyúttal lehetöséget nyújthat a kockázatok csökkentésére, amelyek: kirekesztés, egyenlötlenség, koncentráció. Az időseket tekintve a digitális innovációk az általános és a fogyasztói jóllétükhöz járulhatnak hozzá (Kósa, 2018).

Az infokommunikációs eszközök használata csökkentheti az idös személyek magányát, növelhetik a biztonságérzetüket.

Az egészségi állapotuk folyamatos nyomon követése és monitorozása lassithatja az egészségromlás ütemét (DJP 2.0:83).

Kézzelfoghatói elöny lehet, hogy a digitalizációval, az internet hozzáféréssel „, kinyilik a világ”, addig elérhetetlen vagy nehezen elérhetö információkhoz, ismeretekhez juthatnak hozzá az idösebb korosztályok is. A családi, rokoni és baráti kapcsolatok fenntartását is megkönnyítik az új infokommunikációs lehetöségek, ami távol élök esetén minöségi ugrást jelent (pl. tengerentúlon élö családtag, unoka). Az új eszközök és technológiák megismerése mentális eröfeszitést igényel, a használat folyamatos tanulással jár együtt, ami hozzájárulhat az idös emberek mentális fittségének felébresztéséhez, fenntartásához. Ha ebben a folyamatban fiatalabb családtagok, ismerösök segítik öket, az azon túl, hogy intergenerációs hasznot hoz, szorosabbá is füzheti ezeket a kapcsolatokat.

A digitalizáció negatív hatásai is szerteágazóak. A szülökkel, nagyszülökkel, rokonokkal és egyéb személyekkel fenntartott virtuális kapcsolat „felmentheti” a résztvevőket a személyes találkozás alól. Azonban a személyes találkozásokat, a valódi szemkontaktust, a kézfogást és öleléseket az idős személyek egyre kevésbé tudják nélkülözni (Pinker, 2014). Ezek hiánya negatívérzések elöretöréséhez, elszigeteltséghez, magányhoz vezethet. Egyéb járulékos hatások is léteznek, mint például az okos telefonok gyakori töltési igényéböl vagy a lemerült eszközök kiesö funkciójából fakadó kellemetlenségek, de az internetre véletlenül vagy meggondolatlanul, 
esetleg szándékos károkozásból kikerülö tartalmak (szöveges, fotó, videó) is okozhatnak feszültségeket.

Megjelent az internet- és okoseszköz-függöség, ami az idösebb generációkat ugyanúgy érintheti, mint a fiatalabbakat. A pornográf tartalmak fogyasztása pszichoszexuális zavarokkal lehet összefüggésben (Kósa, 2018).

A digitalizáció környezetterhelése sokrétü, a zaj szennyezéstöl a rövid élettartamú eszközökön, akkumulátorokon (veszélyes hulladék) keresztül a magas energiafelhasználásig, hogy csak a legegyértelmübbeket emlitsük.

A közlekedési balesetek egyik okozójává is elölépett az utóbbi időben az okoseszköz használat.

\section{Közösségi média és időskorúak}

A korábbiakban már leírtuk, hogy az 55-74 évesek korosztályában évről évre emelkedő tendenciát mutat a közösségi oldalak használata (KSH, 2019). A Baby boomerek internethasználati szokásait áttekintve azt is láttuk, hogy 2017-ben a közösségi oldalak használata 27,9\%-ot képviselt. Ezt megelőzően a MediaQ 2016-os kutatási eredményeit az internethasználat és okostelefonok rohamos terjedésével magyarázták. Azt találták, hogy az idősebb korosztályok is egyre inkább bevonódtak az elsősorban Facebook uralta (3. ábra) hazai közösségi médiába.

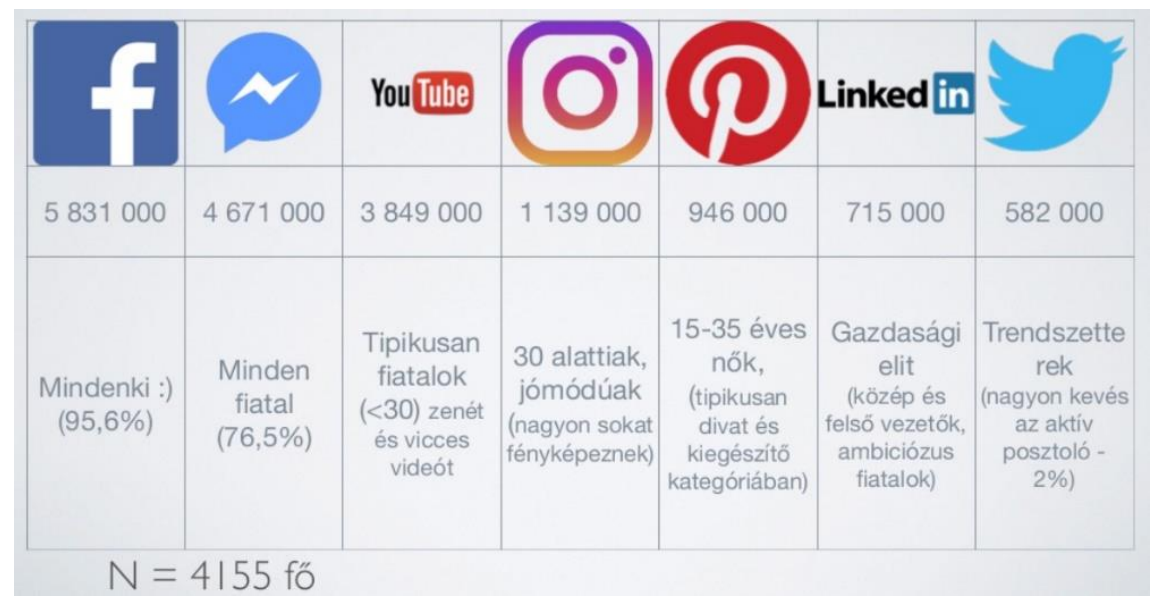

3.ábra. A legnépszerübb közösségi oldalak aktív (heti) fogyasztói Magyarországon (2016 nov.) (MediaQ, 2017:12) 
Az 1945-1965 között született fogyasztókat a MediaQ 2016-os kutatása lassan alkalmazkodó, új belépőkként jellemzi a közösségi médiapiacon, akik a Facebook életmód oldalainak legnagyobb fogyasztói.

Megvizsgálva az idősebb generációkat tömörítő közösségi oldalakat, azt látjuk, hogy jelenleg az egyik legtöbb taggal, több mint 100 ezer taggal rendelkező 2016-ban létrehozott Nyugdíjasok facebook csoport (net1).

A korábbi legnépszerübb facebook csoport a 2015-ben létrehozott Nyugdíjasok oldala zárt facebook csoport (net2) A csoport adminisztrátorai négy szabályt emelnek ki:

„Tilos a politika. A csoportnak a pozitív élmény a célja, amibe a politikai sárdobálás nem fér bele, így kérjük, hogy mindenki máshol politizáljon!

Tilos a hirdetés és a kéretlen tartalom. Nyújts pozitív teljesítményt ebben a csoportban. Az önfényezés, a kéretlen tartalmak és a nem a témába vágó hivatkozások megosztása nem megengedett.

Tilos a gyülöletbeszéd és a megfélemlítés. Fontos! Tégy te is róla, hogy mindenki biztonságban érezhesse magát!

Légy kedves és udvarias! Mindannyiunk közös feladata, hogy befogadó környezetet teremtsünk. Bánjunk mindenkivel tisztelettel. Az egészséges vita természetes, de a kedvesség elengedhetetlen.” (net2)

Az általánosan időseknek szóló csoportok mellett a tematikus, illetve településhez, helyszínhez vagy közösséghez kötődő csoportok száma jelentős és folyamatosan változik. Baráti közösségek is létrehoznak föként zárt csoportokat vagy chatszobákat.

A Szenior örömtánc csoportok oldalainak sok követője van, legtöbben a 2014-ben indított Szenior Örömtánc Szilviával 1530 követővel (net4). Jelentős létszámmal működik a Szenior atléták 1100 követő (net5) csoportja is. A felsőfokú oktatási intézményekhez kapcsolódó idősoktatási kezdeményezések közül jelenleg is a legaktívabb facebook csoportja a Pécsi Szenior Akadémiának van 471 követővel (Bene, 2017; net6).

A 101 évesen 2020 júniusában elhunyt Bálint György, ismertebb nevén Bálint gazda a nyitottság és az összefogás erejében hitt. A haláláig aktív kertészmérnök 98 évesen lejárt jogosítványát már nem hosszabbíttatta meg, viszont saját, aktív (folyamatosan új tartalmakkal bővülő) honlapját még ma is üzemeltetik (net7). Facebook profilját 2010-ben hozták létre, jelenleg több, mint 489.000 követöje van (net8).

Arra is találunk példát a virtuális térben, hogy egy új karriert épít valaki a nyugdíjas éveiben. Arató András 74 éves, eredeti szakmáját tekintve villamosmérnök „Hide the pain Harold” 
néven internetes mém lett az arcképéből. Számára a véletlen ismertség egy új karrierutat nyitott meg a nyugdíjas éveiben. Ugyan őt „csak” alig több, mint 440.000-en követik (net9), viszont TED előadást tartott ${ }^{1}$, internetes tartalmakat szolgáltat milliós nézettségekkel (Arató, 2019). Ö a Coca-Cola 2019-es reklámarca.

\section{Hatások}

A közösségi oldalak hatásai nagyban hasonlitanak a digitalizáció hatásaihoz.

Ugyan a közösségi oldalak biztositják a gyors, hatékony és folyamatos kapcsolattartást, nem helyettesithetik a személyes találkozásokat (Pinker, 2017).

A közösségi oldalak nyújtotta gyors és közvetlen kommunikáció megkönnyitheti a személyes találkozások létrejöttét a kapcsolatfelvétel, az egyeztetések, az eseményszervezés lehetöségével. A közösségi oldalakon sikeres idös személyek énhatékonysága és önbizalma nő. A kapcsolatrendszerüktöl függően befolyásra tehetnek szert, ami felelösséggel jár. Igaz ez minden megnyilvánulásukra a közösségi térben.

Az internet nyújtotta eszköztár lehetöséget biztosithat a szakmai aktivitás meghosszabbitására, esetleg új karrier épitésére.

Itt emlitjük a korábbiakban nem tárgyalt olyan negativ hatásokat, mint a virtuális valóság torzításai és az internetes bünözés.

\section{Tanulás, ismeretszerzés új útjai}

A gerontológiai kutatások eredményei is alátámasztják, hogy azok az idősek, akik mozgékonyak, aktívak és nyitottak, valamint megőrzik vagy akár gyarapítják társadalmi kapcsolataikat, teljesebb öregkorra számíthatnak. A kor előre haladásával nem hanyatlik sem feltétlenül, sem egységesen a kreativitás, az intelligencia, a műveltség. Az idegsejteknek öregedési folyamat során történő leépülése ellensúlyozható a közöttük levő kapcsolatok tanulással való megerősítésével, megújításával (Iván, 1997; Fülöp, 2011). Ma már ahhoz sem fér kétség, hogy az időskori aktivitás fenntartásának egyik leghatékonyabb eszköze a tanulás. Az időskori tanulás színtere egyaránt lehet a formális és nem formális oktatásban (Bajusz, 2016), és természetesen ma már történhet fizikai jelenléttel, online vagy hibrid formában, nagy közösségekben, kis csoportokban, párban vagy önállóan.

\footnotetext{
${ }^{1}$ https://www.youtube.com/watch?v=FScfGU7rQaM TED elöadásának nézettsége: 6555 454, 2020. szeptember 23-án 15:00-kor.
} 
Az időskori tanulás az új technológiák iránti fogékonyságot is növelheti. Az OECD adatai alapján Magyarországon jelentős különbség van az 55-74 éves korcsoport internethasználatában az iskolai végzettség alapján a magasabb iskolai végzettségűek javára (OECD, 2017). Az időskor azonban lehetőséget adhat az önképzésre, új területek felfedezésére, a korábban elhalasztott tanulmányok bepótlására. Az IKT képzések alapos differenciálásával, (testreszabással) biztosítható, hogy az érdeklödők bármilyen tudásszinttel belépjenek a képzésbe.

A különböző korosztályok média fogyasztási szokásait feltárva a 40 év fölötti a korosztályban a top témák a gasztronómia és az életmód, otthon és háztartás. Újra előtérbe kerül a tudományos, ismeretterjesztő tartalomfogyasztás is (Hack-Handa \& Pintér 2015).

\section{Idősakadémiák}

A felsőoktatási intézményekhez kapcsolódó idősoktatási kezdeményezések általában az intézmények társadalmilag felelős tevékenységeként jelennek meg (Corporate Social Responsibility, CSR, harmadik misszió) (Sitku, 2019; Bene, 2017).

Olyan oktatási formák ezek, amelyekben a motivált résztvevők jólléte és az oktatói jóllét növekedése egyaránt prognosztizálható (Kun \& Gadanecz, 2020; Kun \& Szabó, 2017; Jenkins, \& Wiggins 2015).

Ma országszerte több, mint 20 helyszínen kínálnak felsőoktatási intézményi háttérrel olyan oktatást idős személyeknek, amely igazodva a felsőoktatáshoz szemeszterekben, tudományos igényességgel zajlik ${ }^{2}$. A szemeszterek plenáris előadásokból állnak. Gyakran az előadók maguk is idős személyek, nyugdíjas vagy még aktív oktatók, kutatók. Néhány helyszínen szemináriumokat, tréningeket, intenzív kurzusokat is kínálnak a résztvevők számára. Az informatika és digitális eszközhasználat oktatása folyamatosan felmerülő igény.

Az előadások sokszínűségéről ad képet a Kelet-Magyarországi Szépkorúak Akadémiájának utolsó megvalósult szemesztere (Nyíregyháza, 2019/2020 1. félév) (Patyán \& Bene 2019):

- 2019. október 9. szerda 15:00 Cserbán Józsefné (Kuratóriumi elnök, Modus Alapítvány): Önállóság, biztonság és aktivitás digitális eszközök használatával

- 2019. október 16. szerda 15:00 Dr. Végh László (fizikus): A fenntartható élet felé vezető úton

- 2019. október 30. szerda 15:00 Prof. Dr. Semsei Imre: Az öregedés müvészete IV.

\footnotetext{
${ }^{2}$ A karantén-intézkedések folyományaként a 2019/2020 tanév II. félévének és a 2020/2021 tanév I. félévének hagyományos előadássorozatai nem indultak el az intézményekben.
} 
- 2019. november 13. szerda 15:00 : Jámbor Katalin (gyógytornász) és Stéhné Ormai Magdolna (aktív jógázó, szenior örömtánc oktató): Idős emberek fizikai tréningje, preventív mozgásformák, egyensúly, tánc

- 2019. november 27. szerda 15:00 Bene Ágnes, Nagy Luca (PhD hallgatók, pszichológusok): Kreativitás és idősek: reklámok idősekkel, időseknek

- 2019. december 11. szerda 15:00 Dr. Dufek Mihály: Nagy énekesek. Zenetörténeti kitekintés

Magyarországon jelenleg nincs olyan idősakadémia, ami kifejezetten online kurzusokat kínál. A hozzáférhető nemzetközi jó gyakorlatért nem kell messze menni. A szlovákiai U3A-ban ${ }^{3}$ Pozsonyban indítanak online kurzusokat, amiket számos ICT (információs és telekommunikációs) kurzus előzött meg, hogy a résztvevőknek ne jelentsen gondot az ebbe az oktatási formába történő bekapcsolódás (net12). A Harmadik Kor Egyeteme (HKE, University of the Third Age, U3A) mozgalom megújítói már 1997-ben felvetették az internetes idősoktatás lehetőségét, segítve ezzel az izoláltan élő idős személyek bevonását Ausztráliában, ÚjZélandon és az Egyesült Királyságban. 1998-ban el is indult az első ilyen 3 éves kísérleti program az Ausztrál Szövetségi Kormány finanszírozásával (Swindell, 2002). Ugyan az online oktatási forma költségesebben indítható (tananyagok elkészítése, infrastruktúra, a hallgatók és oktatók felkészítése), de a költségek idővel csökkennek, és, mint általában a felsőfokú idősoktatásban, itt is nagy szerepet játszhatnak az önkéntesek munkaórái. Az online oktatás Ausztráliában azóta is zajlik, Swindell 2012-es tanulmányában számol be olyan további időszakokról, amelyekben jelentős forrással támogatta a kormányzat a rendszert.

Számos hazai idősakadémia jelen van valamilyen formában az online térben (Bene, 2017). A legaktívabb közösség a Pécsi Szenior Akadémia facebook oldalához kapcsolódik. Ezen az oldalon az aktuális előadások ismertetésén és a beszámolókon túl, szabadidős tevékenységek, például természetjárás, szervezése is folyik (net6). A szegedi felsőfokú idősoktatás platformja a Szegedi Idősek Akadémiája a Senior Center szervezésében. Az ő facebook közösségük ${ }^{4}$ is aktív (net10). Követendő példa, hogy minden Akadémiájukon elhangzott előadás elérhető a Youtube-on is (net11), elérve ezzel azokat az idős személyeket, akik valamely okból nem tudnak részt venni a helyszíni előadásokon.

\footnotetext{
${ }^{3}$ Comenius University in Bratislava Centre for Continuing Education, University of the Third Age

${ }^{4} 705$ követője van az oldalnak.
} 


\section{Hatások}

Az idöskori tanulásnak a szellemi fittség biztositásán keresztül az aktív idösödés megvalósitásában van döntő szerepe. Az új ismeretek megszerzése és az új ismeretségek kialakitása hozzájárulhatnak az idős személyek jóllétéhez. Az időskori tanulás remek időtöltés. Az idősoktatásban és a hozzá kapcsolódó kommunikációs platformokon keresztül olyan hasznos információk birtokába kerülhetnek az idös személyek, amelyek segitségükre lehetnek valós vagy látens igényeik kielégitésében.

A rendszeres alkalmak - például egy idősakadémia elöadásai - segítenek az idő strukturálásában, az elöadás elött a felkészülés-tervezés folyamatában, az elöadáson a részvétellel és ismerösi-baráti kapcsolatok ápolásával is, az elöadást követöen pedig a lecsengés folyamataival.

A sikeres tanulás növeli az idős személyek önbizalmát, énhatékonyságát. A közösségben társas támaszra találnak.

Nehézséget jelenthet a magányos idős személyek elérése, illetve korlátozza a résztvevők számát a helyszínek nagyvárosokba koncentrálódása, illetve a termek befogadóképessége. Nem várt kihívást jelent a vírus fertözés nyomán bevezetett karantén intézkedések sora. Megoldást jelenthet az online oktatás, az elöadások hozzáférhetöségének biztositása.

\section{Összegzés}

A XXI. századi innovációk gazdasági és társadalmi hatásai minden generációt érintenek. A mai magyar elöregedő társadalomban különösen fontos, hogy az idősebb korosztályok szemszögéből is megvizsgáljuk ezeket a hatásokat. Az idősek társadalmi szerepének egyik kulcsfogalma az aktivitás. Az aktív idősödésben ötvöződik a fizikai, a szellemi és a társas aktivitás. Minden olyan törekvés, ami ezen folyamatokat segíti, pozitív hatásként, és minden olyan folyamat, ami az aktív idősödést gátolhatja, negatív hatásként értelmezhető. Vannak olyan hatások is, amelyek az emberi életkortól függetlenül, minden embert érintenek, ilyenek például az életszínvonal általános emelkedése vagy a környezetkárosítás.

Jelen tanulmány a digitalizáció és a digitalizációval is összefüggő innovációk idősebb korosztályokat érintő hatásaira fókuszál.

Az internet hozzáféréssel és a közösségi oldalak kínálta lehetőségekkel az idősebb korosztályok számára „kinyílik a világ”. A nyugdíjas lét kínálta új élethelyzetben ez biztosíthatja az új készségek és ismeretek elsajátításán túl (szellemi frissesség), a rokoni, baráti kapcsolatok felelevenítését (társas támasz), a szabadidő megszervezését. Az új technológia és az eszközök 
az általános fogyasztói jóllétet növelhetik. Az infokommunikációs eszközök használatával visszaszorítható az elmagányosodás, növelhető a biztonságérzet. Az innovációk alkalmazásában sikeres idős személyek énhatékonysága és önbizalma nő. Az új eszközök és technológiák megismerése mentális erőfeszítést igényel, a használat folyamatos tanulással jár együtt, ami hozzájárulhat az idős emberek mentális fittségének felébresztéséhez, fenntartásához. Ha ebben a folyamatban fiatalabb családtagok, ismerösök segítik öket, az azon túl, hogy intergenerációs hasznot hoz, szorosabbá is füzheti ezeket a kapcsolatokat.

Az időskori tanulás jó időtöltés, ami segíthet az idő strukturálásában is. A szenior tanulók szellemi aktivitásuk fenntartásával új ismeretekkel, készségekkel gyarapodhatnak, és a meglévő baráti, ismerősi kapcsolataik mellé újakkal gazdagodhatnak.

Az innovációk kockázatait, negatív hatásait is tudatosítani kell, mert így lehetőség nyílhat a kezelésre, az esetleges mérséklésükre.

A digitalizáció negatív hatásai is szerteágazóak. A hozzátartozókkal fenntartott virtuális kapcsolat „,felmentheti” a résztvevőket a személyes találkozás alól. Ezek hiánya negatív érzések előretöréséhez, elszigeteltséghez, magányhoz vezethet. Számolni lehet olyan kudarcokkal is, amik az új eszközök használatához kapcsolódnak. A kudarcélmény önbizalom- és énhatékonyság csökkenéshez, szégyenérzethez vezethet. Az internet- és okoseszköz-függőség, az idősebb generációkat ugyanúgy érintheti, mint a fiatalabbakat. A közlekedési balesetek egyik okozójává is előlépett az utóbbi időben az okoseszköz használat.

Egyéb járulékos hatások is léteznek, mint például az okostelefonok gyakori töltési igényéből vagy a lemerült eszközök kieső funkciójából fakadó kellemetlenségek. Az internetre véletlenül vagy meggondolatlanul, esetleg szándékos károkozásból kikerülő tartalmak (szöveges, fotó, videó) is okozhatnak feszültségeket. Növekvő veszélyt jelenthetnek a virtuális valóság torzításai és az internetes bünözés.

A digitalizáció környezetterhelése sokrétű, a zaj szennyezéstől a rövid élettartamú eszközökön, akkumulátorokon (veszélyes hulladék) keresztül a magas energiafelhasználásig terjed.

A közösségi programokra általánosan is igaz, ami az idősoktatásra hatványozottan, hogy nehézséget jelenthet a magányos idős személyek elérése, illetve korlátozza a résztvevők számát a helyszínek nagyvárosokba koncentrálódása, illetve a termek befogadóképessége.

A 2020-as év olyan kihívást hozott a karantén intézkedésekkel, amely még inkább előtérbe helyezte a digitális megoldások alkalmazását. Valós lehetőségként kell számolni az online oktatással, az előadások hosszú távú hozzáférhetőségének biztosításával, a kooperatív online tanulási módszerek alkalmazásával az idősebb korosztályok esetében is. 


\section{Köszönetnyilvánítás}

A kutatás az EFOP-3.6.1-16-2016-00022 „Debrecen Venture Catapult Program” pályázati támogatásával valósul meg.

\section{Irodalomjegyzék}

Arató A. (2019). Waking up as a meme-hero, TEDx Kyiv elérhető: https://www.youtube.com/watch?v=FScfGU7rQaM letöltés: 2019. december 16.

Bajusz K, Jászberényi J. (2013). Az időskori tanulásról, Kultúra és közösség, IV. évfolyam 2013/III. szám pp. 59-66.

Bajusz K. (2016). Az időskori tanulás trendjei Magyarországon. A Pécsi Szeniorakadémia, In: Mintaprogram a minőségi Időskorért Nemzetközi Konferenciakiadvány, pp. 5-9.

Bene, Á., Balázs, K., Kun, Á. (2019). Időseknek szóló fogyasztóvédelmi program In: Lippai, Edit (szerk.) Összetart a sokszínűség : A Magyar Pszichológiai Társaság XXVIII. Országos Tudományos Nagygyülése kivonatkötet Debrecen, Magyarország : Debreceni Egyetem Bölcsészettudományi Kar Pszichológiai Intézet, pp. 220-221.

Bene, Á. (2017) Idősoktatás felsőfokon, Magyar Gerontológia 9: pp. 49-70.

Ehlers, A., Hess, M. (2019). Country-specific Contexts of Technology Usage in Old Age. konf. ea. 14. Gemeinsamer Österreichisch-Deutscher Geriatriekongress; 59. Kongress der Österreichischen Gesellschaft für Geriatrie und Gerontologie 2019 25. - 27. April 2019 Universität Wien, Österreich

Fülöp E. M. (2011). Az idősek kommunikációja, Gerontoedukáció, 2011/2. 1. évfolyam 3. szám, pp. 4-47.

Gallisti, V., Rohner, R. (2019). Digital Literacy of older Adults and its Impacts on Health Literacy, konf. ea. 14. Gemeinsamer Österreichisch-Deutscher Geriatriekongress; 59. Kongress der Österreichischen Gesellschaft für Geriatrie und Gerontologie 2019 25. - 27. April 2019 Universität Wien, Österreich

Hack-Handa, J., Pintér, R. (2015). Generációs különbségek a magyar médiafogyasztásban. Információs társadalom, 15 (2). pp. 7-17. 
Hegyesiné Orsós, É. (2019). A Nyugdíjas Klubok és Idősek „Életet az Éveknek” Országos Szövetsége Szakmai Beszámolója a 2018 évben végzett tevékenységéről, Elérhető: https://eletetazeveknek.hu/images/2020/dokumentumok/beszamolo_szoveges_2018.pdf letöltés: 2020.09.11.

Iván László (1997). Ne féljünk az öregségtől. Sub Rosa, Budapest.

Jenkins, A. - Wiggins, R. D. (2015). Pathways from adult education to well-being: The Tuijnman model revisited. International Review of Education 2015, (61) 1 pp. 79-97

Kleisz, T. (2016). Az időskorúak tanulása Tudásmenedzsment, XII. évfolyam 2. különszám, 2016. december 24-33.

Kósa, K. (2018). A digitalizáció egyéni szociálpszichológiai és társadalmi hatásai. ea. in 21. Digitális Jólét Fórum, Debreceni Egyetem, 2018.12.01.

Kun, Á., Szabó, A. (2017). Boldogság tényezők a pedagógusok munkájában Magyar Pszichológiai Szemle 72:(3) pp. 281-310.

Kun, Á., Gadanecz P. (2020). Workplace happiness, well-being and their relationship with psychological capital: A study of Hungarian Teachers Current Psychology 39 Paper: s12144019-00550-0,

KSH (2019). Digitális gazdaság és társadalom, $2018 . \quad$ Elérhető: https://www.ksh.hu/docs/hun/xftp/idoszaki/ikt/ikt18.pdf letöltés: 2020.11.14.

KSH (2018). Internethasználati szokások, - infografika, Elérhető: http://www.ksh.hu/infografika/2018/internethasznalat.pdf letöltés: 2020.11.12.

Logan, J. R., Ward, R., \& Spitze, G. (1992). As old as you feel: Age identity in middle and later life. Social Forces, 71(2), pp. 451-467.

Magyar Köztársaság Kormánya (2017). A Digitális Jólét Program 2.0 Budapest, 2017. július Elérhetö:https://www.kormany.hu/download/6/6d/21000/DJP20\%20Strat\%C3\%A9giai\%20T anulm\%C3\%A1ny.pdf letöltés: 2020.01.23.

MediaQ (2017). Generációk és online platformok Magyarországon. Közösségi média 2017 Szimpózium, 2016.12.06. Budapest, Elérhető: https://www.slideshare.net/cousteau/mqkozossegi-konditeremszimpozium20161206 letöltés: 2019. szeptember 29.

Mile, Zs. (2019). Digitális OkosNagyi Klub az időseknek, EPALE, Elérhető: https://epale.ec.europa.eu/hu/blog/digitalis-okosnagyi-klub-az-idoseknek letöltés: 2020.10.01. 
Molnár, S. (2020). Az idősödő társadalom társadalmi idősödésének programja Kecskeméten.

Magyar Gerontológia, $\quad$ 12(Különszám), 41-43.

https://doi.org/10.47225/MG/12/Különszám/8474

Monostori, J. (2015). Öregedés, nyugdíjba vonulás. In: Monostori, J; Öri, P \& Spéder, Zs. (szerk.): Demográfiai portré 2015.2 Elérhető: https://demografia.hu/kiadvanyokonline/index.php/demografiaiportre/article/view/2470/2477 letöltés: 2020. szeptember 10.

Montepare, J. M., \& Lachman, M. E. (1989). " You're only as old as you feel": Self-perceptions of age, fears of aging, and life satisfaction from adolescence to old age. Psychology and aging, 4(1), pp. 73-78.

Móré M. (2015). A menedzsmenttudomány válasza az öregedő társadalom kihívásaira Magyar Gerontológia, 7.:(25) pp. 60-71.

OECD (2015). OECD Digital Economy Outlook 2015, OECD Publishing, Paris. DOI: http://dx.doi.org/10.1787/9789264232440-en

OECD (2017). OECD Digital Economy Outlook 2017, OECD Publishing, Paris. DOI: http://dx.doi.org/10.1787/9789264276284-en

Patyán, L. (2018). Időskorúak életminősége 2008 - 2018 Acta Medicinae et Sociologica 9 : 27 pp. $125-137$.

Patyán, L., Bene, Á. (2019). Kelet-Magyarországi Szépkorúak Akadémiája, Nyíregyháza, 2019/2020. első félévének programja, - munkaanyag

Pihlainen, K., Kärnä, E., Koupio, J. (2019). Digital Literacy: Older Adult's Learning with Digital Technologies. konf. ea. 14. Gemeinsamer Österreichisch-Deutscher Geriatriekongress; 59. Kongress der Österreichischen Gesellschaft für Geriatrie und Gerontologie 2019 25. - 27. April 2019 Universität Wien, Österreich

Pinker, S. (2014). The village effect: Why face-to-face contact matters. Atlantic Books Ltd.

Pinker, S. (2017). The secret to living longer may be your social life. TED talk, 2017.09.04. Elérhetö: https://www.youtube.com/watch?v=ptIecdCZ3dg letöltés: 2019.03.23.

Libicki Éva, R. Fedor Anita (2020). A szubjektív egészségi állapot kutatási hátterének többszintü megközelítése a társadalmi egyenlőtlenségek tükrében, ACTA MEDICINAE ET SOCIOLOGICA $11: 31$ pp. 13-25 
Semsei I. (2015). Az öregedés müvészete I. Magyar Gerontológia, 7:(27) pp. 3-17.

Semsei I. (2016). Az aktív időskor kérdései a XXI. században Tudásmenedzsment, 17:(2) pp. 7-10.

Sitku K. (2019). Vidéki egyetemek harmadik missziós tevékenysége: a társadalmi tudásmegosztás hatásai. A magyar szakirodalom áttekintése Iskolakultúra: Pedagógusok Szakmai-Tudományos Folyóirata $29: 8$ pp. 17-35.

Swindell R. (2002). U3A Online: a virtual university of the third age for isolated older people, International Journal of Lifelong Education, 21:5, pp. 414-429.

Swindell, R. (2012). Successful ageing and international approaches to later-life learning. In Active ageing, active learning (pp. 35-63). Springer, Dordrecht

Sz. Molnár, A. (2005). Az idõs felnõtt rétegek (45 év felettiek) felnõttképzési igényei és képzési lehetõségei, Kutatási zárótanulmány, Felnõttképzési Kutatási Füzetek, Elérhető: https://vmek.oszk.hu/06500/06528/06528.pdf letöltés: 2019.04.24.

Ujváriné Siket, A.; Fehér, E.; Keszler, Á. \& Zrínyi, M. (2020). Az ápolási készségek újradefiniálása a robotizáció és az AI területén az ápolásban Magyar Gerontológia 12 : Különszám pp. 57-58.

Williams, J. A., Weakley, A., Cook, D. J., \& Schmitter-Edgecombe, M. (2013, June). Machine learning techniques for diagnostic differentiation of mild cognitive impairment and dementia. In Workshops at the twenty-seventh AAAI conference on artificial intelligence.

1456/2017. (VII. 19.) Kormány határozat a Nemzeti Infokommunikációs Stratégia (NIS) 2016. évi monitoring jelentéséről, a Digitális Jólét Program 2.0-ról, azaz a Digitális Jólét Program kibővítéséről, annak 2017-2018. évi Munkaterve elfogadásáról, a digitális infrastruktúra, kompetenciák, gazdaság és közigazgatás további fejlesztéseiről

\section{Internetes hivatkozások}

net1 Nyugdíjasok facebook oldal oldal Elérhető: https://www.facebook.com/NyugdijasokOldala/?ref=page_internal letöltés: 2020. november 23.

net2 Nyugdíjasok oldala facebook oldal Elérhető:

https://www.facebook.com/groups/szulinapi/about letöltés: 2020. szeptember 23. 
net4 Szenior Örömtánc Szilviával facebook oldal Elérhető: https://www.facebook.com/Szenior-\%C3\%96r\%C3\%B6mt\%C3\%A1nc-Szilvi\%C3\%A1val523453914422410/ letöltés: 2020. szeptember 23. net5 Szenior atléták facebook oldal Elérhető: https://www.facebook.com/groups/413599432066402/members/ letöltés: 2019. szeptember 29. net6 Pécsi Szenior Akadémia facebook oldal Elérhető: https://www.facebook.com/pg/szeniorakademia/community/?ref=page_internal letöltés: 2020. szeptember 23.

net7 Bálint György (Bálint gazda) honlapja Elérhető: https://balintgazda.hu/ letöltés: 2020. szeptember 23.

net8 Bálint gazda facebook oldala Elérhető: https://www.facebook.com/balintgazda/ letöltés: 2020. szeptember 23.

net9 Arató András facebook oldala Elérhető: https://www.facebook.com/aratoa letöltés: 2020. szeptember 23.

net10 Szegedi Senior Center facebook oldala Elérhető: https://www.facebook.com/seniorcenterszeged/ letöltés: 2020. szeptember 23.

net11 Szegedi Idősek Akadémiája előadások a youtube-on: https://www.youtube.com/results?search_query=Szegedi+Id\%C5\%91sek+Akad\%C3\%A9mi \%C3\%A1ja\%3A letöltés: 2020. szeptember 23.

net12 Comenius University in Bratislava Centre for Continuing Education, University of the Third Age honlap, Elérhető: https://cdv.uniba.sk/en/university-of-the-third-age/ letöltés: 2020. szeptember 11 . 